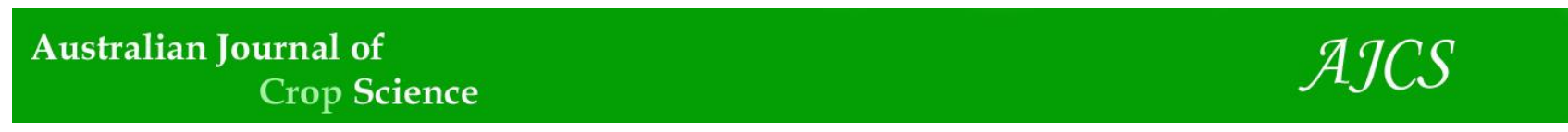

AJCS 11(09):1078-1085 (2017)

ISSN:1835-2707

doi: 10.21475/ajcs.17.11.09.pne347

\title{
Sorghum [Sorghum bicolor (L.) Moench] breeding for resistance to leaf and stalk anthracnose, Colletotrichum sublineolum, and improved yield: Progress and prospects
}

\author{
Maletsema Alina Mofokeng*1,2, Hussein Shimelis ${ }^{2}$, Mark Laing ${ }^{2}$, Nemera Shargie ${ }^{1}$ \\ ${ }^{1}$ Agricultural Research Council, Grain Crops Institute, Private Bag x 1251, Potchefstroom, 2520. South \\ Africa \\ ${ }^{2}$ African Centre for Crop improvement, School of Agriculture, Earth and Environmental Sciences, Private \\ Bag X 01, Scottsville, 3290. South Africa
}

*Corresponding author: MofokengA@arc.agric.za

\begin{abstract}
Sorghum is one of the main staple food crops for millions of subsistence farmers in Africa. Biotic and abiotic challenges are the major production constraints of the crop. Amongst the sorghum biotic constraints, anthracnose is the major devastating disease causing up to $80 \%$ of yield reduction. The productivity and profitability of sorghum is limited by several biotic constraints, most notably anthracnose caused by the aggressive fungal pathogen Colletotrichum sublineolum. The most effective and environmentally responsible strategy to control anthracnose is through the incorporation of resistance genes. However, although several sources have been identified, the lack of information with regard to its genetic control of resistance has limited their adequate use in breeding programs. Additionally, the limitations of breeding regarding the leaf and stalk anthracnose resistance and also the need for evaluating materials for resistance and yield in different environments is of major importance. There is limited information about the combining ability, gene action and genetic effects and relationships between anthracnose resistance and grain yield which is required in devising appropriate strategies for developing resistant and high yielding sorghum varieties. This review provides theoretical basis of the progress and challenges for breeding sorghum for anthracnose resistance and improved yield.
\end{abstract}

Keywords: Anthracnose, pest control, resistance, sorghum.

\section{Introduction}

Sorghum [(Sorghum bicolor (L.) Moench] is one of the most important grain crops grown worldwide for food security. It ranks fifth after wheat, maize, rice, and barley (FAO, 2011) globally and second after maize in Sub-Saharan Africa (Zidenga, 2004). It grows in the tropical and sub-tropical areas of the world with the four wild and the cultivated races differentiated by head type, grain size, yield potential, and adaptation, among other traits (Acquaah, 2007). The cultivated races include bicolor, guinea, kafir, caudatum, and durra (Acquaah, 2007). Some intermediate races are also recognised.

Sorghum is produced in areas considered marginal for other cereal crops such as maize. According to Vijayakumar et al. (2014) sorghum produced worldwide is 64.20 million tonnes with a cultivated area of 41 million hectares. Of this, about 26 million tonnes are produced in Africa. The four leading sorghum producers in Africa are Nigeria, Ethiopia, Burkina Faso and Niger. About 74\% of sorghum in Africa is used for food (Acquaah, 2012). Although the production varies widely among countries, sorghum remains an important food constituent in the diet of many rural households.

Apart from its contribution to food security, sorghum is broadly adapted and can be grown in a wide range of environments. One of its strongest traits is its great adaptability to tropical and subtropical areas of the world where water availability and soil conditions are marginal for other grain crops such as maize (ICRISAT, 2009). It can be produced in a wide variety of soil types, but yields are typically highest in deep, well drained soils with good fertility. It also appears to have a high capacity for osmotic adjustment to stress to maintain turgor pressure in cells (Nguyen et al., 1997), while some sorghum varieties possess "stay green" genes that enable them to continue to photosynthesize post-flowering, during drought (Borrel et al., 2014). Because of these abilities to survive in harsh conditions it is a vital crop for household food security for many rural communities farming in marginal agro-ecologies, such as in the dry regions of South Africa, Botswana and Namibia. Among the cereals, sorghum is known to have the greatest number of diseases (Esele, 1995). This is partly because it is cultivated under a wide range of environmental conditions.

There are various biotic and abiotic stresses that affect the production and productivity of sorghum in various parts of the world. The biotic stresses include damages caused by disease causing organisms, insect pests, weeds, birds, and rodents. parasitic weeds. The most prevalent diseases of sorghum are ergot, grain mould, various smuts, root and stalk rots, leaf diseases such as rust, zonate leaf spot, mildews, anthracnose and leaf blight among others (Dogget, 1988). The insect pests include stalk borers, maize and sorghum aphids, panicle feeding bugs, beetles, bollworms, wireworms, cutworms, weevils, shootfly, sorghum midge, virus diseases and armoured cricket (Dogget, 1988; Van den Berg and Drinkwater 1997). The most common viruses attacking sorghum include Johnson grass mosaic virus, maize dwarf mosaic virus, sugarcane mosaic virus, and sorghum mosaic virus. These viral diseases account for $2-5 \%$ yield loss 
annually. The purpose of this article is to review the anthracnose disease and the progress and challenges for breeding sorghum varieties resistant to the disease and attain improved yield.

\section{Anthracnose in sorghum}

Anthracnose is one of the most devastating fungal diseases in sorghum. The disease is commonly found in tropical and subtropical environments where warm, humid climatic conditions enhance the development and spread of the disease (Thakur and Mathur, 2000).

\section{Symptoms}

The anthracnose disease occurs in the foliar parts of the plant as well as on the stalk and panicle (Figure 1 and 2). The sorghum anthracnose is caused by Colletotrichum sublineolum P. Henn. Kabat; Bulbak which poses a serious threat to sorghum production and profitability (Thakur and Mathur, 2000). The disease occurs in four phases: seedling root rot, leaf (foliar), stalk rot and seed mold. All these phases may occur within a single growing season. The seed rot is mainly due to planting of infected seed or infection of the seeds as they germinate in infested soil. The foliar anthracnose is the most destructive disease phase and it appears 30-40 days after emergence during growth stage 4.0 or later. It occurs from the true leaf through the emergence of the panicle from the boot. The leaf phase of anthracnose begins to develop very quickly near the end of the vegetative stage of the plant and near the beginning of the heading stage. The fungus survives as mycelium, conidia and microsclerotia up to 18 months in crop debris or above the soil surface. In alternative hosts it survives as mycelium in infected seeds. Depending on the cultivar and environmental conditions, the symptoms range from small elliptical spots to elongated lesions with abundant acervuli. Premature defoliation in highly susceptible cultivars which may result in a death of a plant before seed development. The foliar infection occurs at any stage of plant development and may cause yield losses from $20 \%$ up to $80 \%$ (Ali et al. 1987; Marley et al., 2005; Tesso et al., 2012). It can also cause reduction in kernel number and size. Stalk anthracnose develops from spores produced in the foliar phase, and is spread throughout the field by splashing rain and/or wind. The spores germinate and infect the stalk above the uppermost leaf and rot the interior of the stalk. If the head and stalk are split lengthwise, a banded or marbled pattern of dark red to purple lesions interspersed with white pith tissue are seen. In severe cases, infection of the panicles can hinder grain filling. The infected heads generally mature earlier than uninfected and they are smaller and lighter in weight and the movement of nutrients to the grain is also limited. The stalk rots and leads to yield losses due to lodging of susceptible cultivars. The infection on the panicle can cause yield reduction of $30-50 \%$ (Thakur and Mathur, 2000). The infected seeds appear dark brown or black with streaks encircling the seed. Additionally, the infected seeds can cause reduced germination and new introductions/pathotypes of the disease in new regions (Cardwell et al., 1989; Marley et al., 2004). Further, sorghum anthracnose often occurs as a mixed infection with zonate leaf spot in Mali and Nigeria (Bandyopadhyay et al., 1996). Physiological races

The fungus is known to have variable pathotypes. More than 40 races/pathotypes have been reported from different geographical areas of the world using different sets of putative host differentials (Casela and Ferreira, 1995; Marley et al., 2001, 2004; Mathur et al., 2002; Rooney et al. 2002). The $C$. graminicola races were first reported in the United States in 1967 (Haris and Johnson, 1967). Then followed other countries such as Puerto-Rico and the US with 11 races (Ali and Warren 1987; Cardwell et al. 1989), 12 in Brazil (Ferreira and Casela 1986), 15 in Nigeria (Ozula et al., 1986; Marley et al., 2001; 2004) and 2 from West Africa (Neya and Normad, 1998; Thomas, 1995). In Nigeria, nine races of anthracnose were identified amongst diverse strains that have been tested under greenhouse and field conditions (Ozula et al., 1986). In Samaru, five physiological races were identified from 50 foliar isolates collected from sorghum growing areas (Marley et al., 2001). Thomas (1995) reported the presence of two isolates of $C$. graminicola in the Samako area of Bamako, in Mali. Alawode et al. (1983) identified three races of $C$. graminicola based on the symptom types. Based on morphological and cultural characteristics, Marley et al. (2001) identified nine morphological groups from 50 isolates collected from major sorghum producing areas in Nigeria. Anas et al. (2001) found five morphological groups within five isolates gathered from various plant parts infected with the disease. A genetic variation within foliar population of $C$. graminicola was reported in West and Central Africa but limited in Burkina Faso (Thomas and Frederiksen, 1995; Thomas et al., 1995; Neya and Normand 1998). Three races were found among the isolates collected from Georgia, Florida, and Puerto Rico in the US (Ali and Warren, 1987). Mathur et al. (2002) used a set of 15 sorghum differentials grown in 16 locations in Africa, Asia, and the United States. The interactions showed that different pathotypes prevailed at each location. Later, Valerio et al. (2005) reported 22 pathotypes among 37 isolates using an additional differential SC748-5. Moore et al. (2008) established 13 new pathotypes from 87 isolates collected from Arkansas.

\section{Strategies to control anthracnose}

Because of these constraints and the use of traditional cultivars (low yielding) and traditional production practices during early 1970 s, the sorghum production is dismally low. In order to improve and/or maintain yields different control strategies needs to be employed. The anthracnose is managed by the use of fungicides, cultural practices and resistant cultivars (Singh et al., 1989).

\section{Cultural control}

The cultural practices include cleaning fields at the end of harvest and beginning of the season significantly reduces the incidence and severity of anthracnose compared to practices of incorporating crop residues into the soil for enhancement of soil fertility. The management of anthracnose using proper field sanitation as a cultural control measure remains highly sustainable in many regions. A change in planting dates can serve as an alternative means of managing anthracnose in farmer's fields (Park et al., 2005). However, for planting dates to be used as an effective control method in disease management, one has to know the cycle of the disease and find out the optimum time when the diseases reached its optimum/peak levels. Altering of planting dates (Ngugi et al., 2000; Marley 2004), planting disease free seeds, and crop rotation can serve as important methods for controlling sorghum anthracnose disease severity (Warren 1986; Cardwell et al., 1989; Casela and Frederiksen, 1993; Somda et al., 2007). These methods are inexpensive and are environmentally friendly, but may be ineffective especially if they are to be implemented in large fields. 


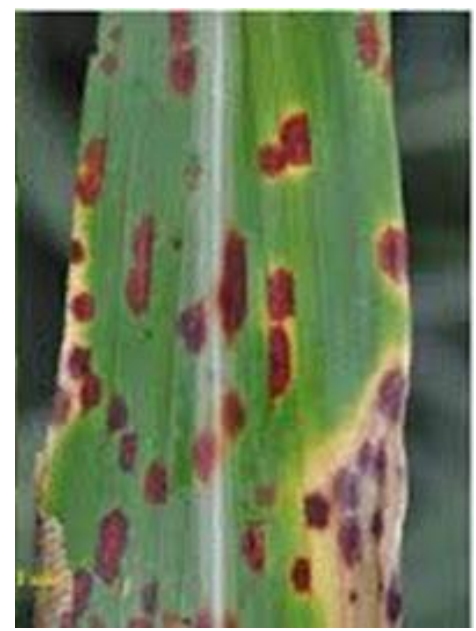

Fig 1. Anthracnose symptoms on sorghum leaf.

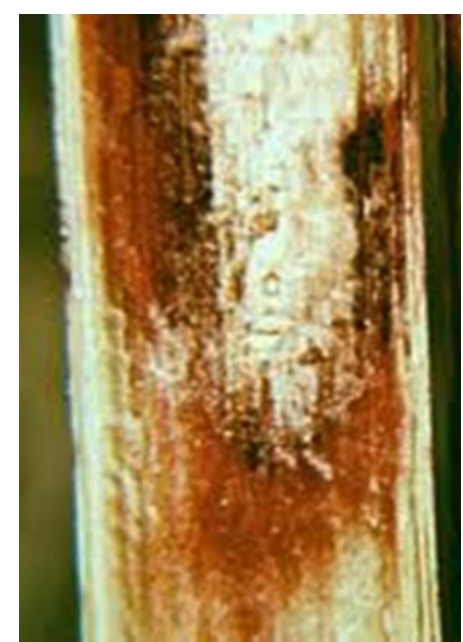

Fig 2. Anthracnose symptoms on the stem.

\section{Chemical control}

The other control strategy of anthracnose disease was the use of fungicides (Gwary and Asala, 2006a). Chemicals such as Apron-plus for seed treatment alongside foliar fungicides such as carbendazin + maneb and mancozeb were applied. These chemicals have been reported to be effective in the controlling anthracnose in Nigeria (Akpa et al., 1992). Other fungicides were reported to be effective in controlling the anthracnose disease (Marley et al. 2004; Gwary and Asala, 2006b). Sorghum seed treatment with vitavax (carboxin) followed by a spray with zined was also the most effective anthracnose control (Michereff et al., 1994). The use of chemicals for control of anthracnose is not economical and sustainable. It is usually costly for farmers who produce sorghum in large quantities globally.

\section{Host plant resistance}

For sustainable agricultural systems, host plant resistance is more effective and provides the most economical method of stabilizing crop production. Several sources of resistance to C. sublineolum have been identified which includes several genes (Thakur and Mathur, 2000). Coleman and Stokes (1954) identified a gene for resistance to anthracnose stalk rot which differed with the gene controlling the foliar phase of the disease. Additional sources of resistance to anthracnose are required due to the occurrence of pathotypes within the pathogen population and changes in virulence patterns for enhancement of durability to resistant sources. $C$. sublineolum has a high level of variability and this variability results in the fast adaptation of the pathogen to the resistant cultivars in use, breaking their resistance very quickly (Singh et al., 2006; Moore et al., 2008; Silva et al., 2008). The use of multilines or mixtures of varieties in the form of non-isogenic lines seemed to be effective in reducing the disease severity (Casela et al., 2001b). Guimaraes et al. (1998) and Costa et al. (2005) analysed this process in the Sorghum bicolor/C. sublineolum pathosystem and assessed the efficiency of sorghum mixtures in controlling anthracnose in Brazil. The genetic variability that is present in the pathogen population indicates that there is potential for the identification of new sources of resistance genes to the pathotypes (Cardwell et al., 1989). This is needed not only to be incorporated in breeding programs, but also to be explored in management strategies to increase the stability of this resistance. Attempts were made to increase the durability of the resistance to anthracnose in sorghum. Strategies such as dilatory resistance, which reduces the rate of development of the disease (Guimaraes et al., 1998), identification of and dissociation of virulence in the population of the pathogen (Casela et al., 2001a) and the use of the mixtures of cultivars (Guimaraes et al., 1998). The use of hybrid development resulting from the combination of male sterile (A) and the restorer ( $\mathrm{R})$ lines against which there is no virulence association in the pathogen population (Casela et al., 1998) seemed to the trick of reducing the disease development. Costa et al. (2005) used a three way hybrids as a strategy to manage resistance to C. graminicola in sorghum. However, little information is available on the strategies for increasing durability of genetic resistance to anthracnose in sorghum.

\section{Plant disease resistance and types}

Plants have developed several defensive mechanisms that enables them to restrict the development of infections. The presence of physical barriers that inhibit the pathogen to penetrate the plant such as thick cuticle layer, size and location of stomata, among others. Plants release chemical compounds into its environment that inhibits pathogen development for example fungitoxic exudates in some plants leaves inhibits fungi development. Compounds such as phenols, tannins and avenacin present in cells offers a good chemical defense mechanism in plants (Agrios, 2004, Heath, 1981). Heath (1981) reported another form of resistance where plants are not considered to be host of the pathogen in question and it is referred to as non-host resistant. The other form of resistance in plants is the one referred to as true resistant. True resistant is genetically controlled which is achieved by a plant through incompatibility between itself (host) and the pathogen (Agrios, 2004). According to (Plank, 1963; Agrios, 2004) true resistance is of two kinds: host resistance (HR) and vertical resistance (VR). HR is the form of resistance that is not specific but rather quantitative and is controlled by many genes hence referred to as polygenic resistance (Agrios 2004). Anthracnose resistance is an example of polygenic resistant since it is controlled by more than one gene (LeBeau and Coleman, 1950; Murty and Thomas, 1989; Tenkouano and Miller, 1993). Costa et al. (2011) reported a dominant resistance to the anthracnose disease. In this form of resistance single gene may not play a role in resistance alone but combining with other genes. HR do not protect plant from being infected but rather slows the development of the disease hence slowing the spread of the disease in the field (Agrios, 2004). VR is a race specific form 
of resistance usually controlled by one major gene or very few genes hence referred to as monogenic resistance. In this form of resistance a cultivar may be resistant to some races of the pathogen and susceptible to other races of the same pathogen (Agrios, 2004). VR is characterized by incompatibility between the host and pathogen and when attacked, the host respond by hypersensitive reaction. Hypersensitive reaction is rapid localized death of host cells in response to infection. HR has long shelf life and difficult to break while VR is easy to break due to continuous pathogen coevolution resulting to arise of new races. To break polygenic resistance a pathogen race must be able to have genes of virulence that can overcome all resistance genes present which is not easy. This is a major advantage of $\mathrm{HR}$, the instability of race specific resistance has prompted the search for more stable forms of resistance. Dilatory resistance, characterized by a slow rate of disease development has been demonstrated in the anthracnose/sorghum pathosystem (Guimaraes et al., 1998). This type of resistance is expressed as a reduced infection frequency, a slower rate of development in the host, and a slower rate of spore production over a short period of time (Parlevliet, 1979). Dilatory resistance to anthracnose was identified in commercial sorghum hybrids in a field study conducted by Cardwell et al. (1988).

\section{The genetics of anthracnose}

Heritability of anthracnose resistance has been researched for over 50 years. In most cases, researchers identify resistance genes that protect against a single isolate of the pathogen and in several cases the resistance is conferred by a recessive allele. Information on the inheritance of sorghum resistance to leaf anthracnose is very scanty. However, Costa et al. (2011) studied inheritance of anthracnose gene using the $F_{1}$, segregating and backcross populations. They found that for most crosses the resistance was dominant, and the proportions of resistant and susceptible plants in the segregating population conformed to the frequencies expected under the hypothesis of gene-for-gene interaction and dominant gene action. There is evidence that resistance to the anthracnose stages to leaf and stalk rot is under independent genetic control (Casela et al., 1997). LeBeau and Coleman (1950) verified that the resistance is controlled by recessive genes, which was confirmed by the studies by Singh et al. (2006) and Boora et al. (1998) using RAPD and SCAR markers for sorghum lineages. In other studies, the inheritance of resistance was reported to be determined by a larger number of genes with partial dominance or an additive effect; by a dominant gene without cytoplasmic influences; or by a single locus with multiple alleles (Murty and Thomas, 1989; Tenkouano and Miller, 1993). Mehta et al. (2005) characterised the inheritance and stability of resistance in the pathosystem at different locations, also concluded that the resistance is controlled by a single locus with dominant or recessive gene action. Sources of dilatory resistance, inherited as a polygenic trait have also been identified (Casela et al., 1993). Erpelding and Prom (2004) evaluated 270 Mali accessions to study the mode of inheritance during the dry and wet seasons in 2003 at Puerto Rico and 41 accessions exhibited both dominant and recessive gene action. Mehta et al. (2005) identified four converted lines that displayed unique but simply inherited sources of anthracnose resistance. Due to the inconsistency of the results on inheritance mechanism the genetics of anthracnose resistant is more complex and remains unclear. This justifies the importance of studying mode of inheritance of genotypes that are used as sources of resistance for anthracnose in every breeding program.

The genetic effect can either be additive, dominant or epistatic and in rare case over dominance. According to Griffing (1956), general combining ability (GCA) and specific combining ability (SCA) are used to estimate gene effects. The GCA is used to estimate additive genetic effects while SCA estimates the non-additive components. There are no studies reported on determination of combining ability effects of anthracnose disease in sorghum. Callaway et al. (1992) studied the effect of anthracnose stalk rot on grain yield and related traits and determined their combining ability on maize adapted to north-eastern United States. The authors found that the general combining ability was significant for kernel weight while the specific combining ability was significant for kernel weight and grain yield. Callaway et al. (1990) also studied the general combining ability effects of anthracnose stalk rot resistance on maize in a diallel analysis. The inbreds LB31B, RD5264, and RD6501 had highly significant negative general combining ability effects for anthracnose stalk rot ratings, indicating that these lines would be good choices as parents where anthracnose stalk rot resistance is desired. The inbreds RD5215, RD5217, RD5529, B59Ht, and B37 had significant, positive general combining ability effects. Specific combining ability was important for certain combinations of lines. Rooney et al. (2011) registered A/BTx2929 through A/BTx2934 for resistance to several disease including anthracnose in the /USA with good combining ability and adaptation. However, there are limited studies on the combining ability effects of anthracnose resistance in sorghum and yield reported thus far. Information on the effects of combining ability aid breeders on the mode of gene action of the desired traits.

\section{Genomic selection for anthracnose resistance}

Breeding for stable anthracnose resistance has been difficult even in regions with endemic anthracnose due to hypervariable nature of the $C$. sublineolum along with strong environmental effects on symptoms development and disease spread. Hence, identification of new sources of resistance is essential. Improved germplasm with resistance to anthracnose has been released previously. Most of the lines are used directly in the commercial hybrid or cultivar production, while others are used in breeding sources but most were developed using traditional breeding methodology. Tenkuano et al. (1993a,b) proposed selection at the seedling stage based on phytoalexin content. Recently, markers linked to anthracnose resistance have been identified (Boora et al., 1998). The molecular markers make the pyramiding of genes feasible and the genes be more stable across environments. Molecular markers linked to gene/s of interest are one possible strategy to allow selection for anthracnose resistance without concern of pathogen pressure.

Differentiation between Collectotrichum isolates based on morphological traits and origin is not sufficient for assessment of genetic diversity. This is due to the influence of environment on the stability of the morphological characters. Molecular markers such as randomised amplified polymorphic DNA (RAPD) (Guthrie et al., 1992) and restriction fragment length polymorphism (RFLP) have been used to examine genetic diversity in the anthracnose pathogen. Valerio et al. (2005) used RAPD and RFLP-PCR markers to examine the molecular diversity of 37 Collectotrichum isolates collected from four distinct regions of Brazil and recorded polymorphic differences among the isolates belonging to the same race as defined on 10 sorghum 
differentials. However, no association between virulence phenotypes and molecular profiles was observed. Figueiredo et al. (2006) used SDS-PAGE, RAPD, ARDRA (amplified rDNA restriction analysis) and rDNA sequencing for identification of $C$. sublineolum pathotypes and concluded that RAPD and rDNA sequencing revealed a high degree of polymorphism among the five pathotypes in Brazil. Wang et al. (2006) used the SSR markers to evaluate genetic diversity in relation to rust and anthracnose disease response on 96 sorghum accessions randomly selected from the core collection database of the Germplasm Research Information Network (GRIN). The information obtained was useful for selection of parents for crosses and classification of sorghum accessions in germplasm management. Chala et al. (2011) determined the presence of genetic diversity using amplified fragment length polymorphism (AFLP) on $102 \mathrm{C}$. sublineolum isolates collected from different sorghum growing areas in Ethiopia. The findings of the study confirmed the presence of a highly diverse pathogen, which concurs with the existence of diverse host genotypes and widely ranging environmental conditions in sorghum growing areas within the country.

Upadhyaya et al. (2013) used association analysis using SNP markers to identify markers linked to anthracnose resistance in sorghum. Eight marker loci were associated with anthracnose resistance in the two years. Except locus 8, disease resistance-related genes were found in all loci based on their physical distance from linked SNP markers. These include two NB-ARC class of $\mathrm{R}$ genes on chromosome 10 that were partially homologous to the rice blast resistance gene Pib, two hypersensitive response-related genes: autophagy-related protein 3 on chromosome 1 and 4 harpininduced 1 (Hin1) homologs on chromosome 8, a RAV transcription factor that is also part of $\mathrm{R}$ gene pathway, an oxysterol-binding protein that functions in the non-specific host resistance, and homologs of menthone:neomenthol reductase (MNR) that catalyzes a menthone reduction to produce the antimicrobial neomenthol. cDNA-AFLP technique was used to identify transcripts differentially expressed in a resistant genotype from Uganda (Biruma et al. 2012). Katile (2007) reported that three AFLP markers (Xtxa607, Xtxa3181 and Xtxa4327) and three SSRs (Xtxp3, Xtxp55 and Xtxp72) identified were loosely linked to the anthracnose resistance genes. They were located in linkage group B and this suggest that markers located $20-30 \mathrm{cM}$ on one side or the other of those tested should provide useful tags for the resistance gene. Felderhoff et al. (2016) used genotyping by sequencing to map anthracnose resistance loci in sorghum. Totals of 5186 and 2759 informative SNP markers were identified in the two bi-parental mapping populations used. Burrell et al. (2015) created a RIL population of 117 inbred lines, and generated 619 SNP and three microsatellite markers to create a genetic map for QTL analysis. After phenotyping for anthracnose symptoms, they identified a QTL on chromosome 5 that colocalized with the QTL identified by Cuevas et al. (2014) and Perumal et al. (2009). Perumal et al. (2009) identified markers that cosegregate with $\mathrm{Cgl}$, a dominant gene for anthracnose resistance identified in cultivar SC748-5 using AFLP and SSR markers. Upadhyaya et al. (2013) mapped eight loci that are linked to anthracnose resistance in sorghum using SNP markers. Some lines were found to have a stable resistance to anthracnose. The lines included IS3547, IS 6958, IS 6928, IS 8283, IS9146, IS 9249, IS 18758, M 35610, A 2267-2 and ICSV 247. Hybrid seed parents such as ICSA/B 260 and ICSA/B 295 were also found to be tolerant to anthracnose (Reddy et al., 2007). Boora et al. (1998) identified markers linked to a recessive gene conditioning anthracnose resistance. Panday et al. (2002) used bulk segregant analysis to identify two RAPD markers linked to anthracnose resistance in sorghum accession SC326-6 and found to segregate as simple recessive trait when crossed with BTx623, a susceptible cultivar. Singh and Boora (2008) used bulk segregant analysis for mapping of resistance genes by RAPD and SSR markers. Perumal et al. (2009) identified an AFLP marker for resistance to anthracnose. Two SNP loci mapped on chromosome 6 co-localized with anthracnose resistance QTL mapped by Murali Mohan et al. (2010) and by Klein et al. (2001).

\section{Effects of genotype by environment interaction on resistance to anthracnose}

Several important and common traits are a composite reflection of multiple genetic and environmental factors (Vulsteke and van Eewijk, 2008). Sorghum is grown in diverse environments across the world. Despite its adaptability to diverse harsh conditions, the crop is very tolerant to environmental variation. This influences most of the economically important traits which are largely inherited quantitatively and delays selection process in breeding programmes. For quantitative traits such as yield the relative performance of cultivars often changes from one environment to another. Extensive research is required to identify genotypes that show minimum interaction with the environments, or possess greatest yield and resistance stability (Saeed and Francis, 1983)

New varieties generally need to be tested at many locations and for several years before being recommended for a given zone. To achieve this goal, multi-environment trials form the core of varietal testing programs. Several studies have investigated the effect of years and/or locations on agronomic traits on grain sorghum genotypes (Ali, 2000). Hovny et al. (2005) reported that most of hybrids were earlier, taller, higher grain yield and heavier in grain weight than their better parent under different environments. Ezzat et al. (2010) reported stability on yield parameters in different environments in sorghum. Breeders must screen for resistance to anthracnose at as many environments as possible to ensure the stability of the resistance trait incorporated in the genetic material under investigation. Callaway et al. (1992) studied the effect of anthracnose stalk rot on grain yield and related traits and they reported that the yield reduction was dependent on the environment. The same results were reported in the study conducted by White et al. (1979) where the authors found that the significant yield reduction due to anthracnose stalk rot was highly dependent on genotype and environment. Rosewich et al. (1998) found that asexual reproduction at a location may give rise in a predominance of one race that is occasionally influenced by genetic drift and gene flow. Thakur et al. (2007) reported differential severity among the lines under study, years and locations. Breeders must screen potentially resistant lines and hybrids in many environments to ensure that the resistance incorporated in their hybrids and cultivars is stable and durable across environments and pathogen race. There is need for comprehensive resistance for protection against different pathotypes in plant breeding programmes. Information on the genotype $\mathrm{x}$ environment interaction on both leaf and stalk anthracnose resistance and yield in sorghum is still limited. 


\section{Conclusion}

Sorghum is an important staple food crop for most communities in the developed and under-developed countries. The crop is not researched thoroughly compared to crops such as maize. Hence, its productivity is not encouraging. The low productivity is aggravated by biotic, and abiotic stress factors. Among the biotic factors, anthracnose is the most important. Breeding for resistance to anthracnose is being challenged by phyto-variability of the pathogen. Identification of durable resistance requires the screening of sorghum genotypes against multiple races of the pathogen at multiple locations. More studies are needed for determination of the environmental effects and stability of the resistance to anthracnose and yield. Future breeding activities should give considerations to untapped resistant genetic material and marker assisted selection to facilitate the screening of the large numbers of germplasm.

\section{Acknowledgments}

The United States Agency for International Development is sincerely appreciated for funding.

\section{References}

Acquaah G (2007) Principles of plant genetics and breeding. 1 st ed. Blackwell, Malden, USA.

Acquaah G (2012) Principles of Plant Genetics and Breeding, Second Edition. Wiley Balckwell.

Agrios GN (2004). Plant pathology. $5^{\text {th }}$ edition. Elsevier Academic Press. San Diego.

Akpa AD, Gana S, Alabi O (1992) Foliar fungicidal spray for the control of some common foliar disease of sorghum in Nigeria. Nigerian J Plant Prot. 14:92-96.

Alawode DA, Manzo K, Sundaram NV (1983) Anthracnose of sorghum in Nigeria. In Proceedings of the $13^{\text {th }}$ Annual Conference of the Nigerian Society for Plant Protection, 710 March. Plant Quarantine Station, Moor Plantation, Ibadan, Nigeria.

Ali MEK, Warren HL (1987) Physiological races of Collectotrichum graminicola on sorghum. Plant Dis. 71:402-404.

Ali MEK. Warren HL, Latin RX (1987) Relationship between anthracnose leaf blight and losses in grain yield of sorghum. Plant Dis. 71:803-806.

Ali MA (2000). Heterosis, combining ability and stability studies in grain sorghum. PhD Thesis. Faculty of Agriculture Assiut University, Egypt.

Anas AI, Marley PS, Akpa AD, Alabi O (2001) Investigations into variation among isolates of Collectotrichum graminicola causal organism of anthracnose of sorghum (Sorghum bicolor) in Nigeria. Samaru J Agric Res. 17:93-103.

Bandyopadhyay R, Hess DE, Sissoko I (1996) Summary report of sorghum pathology activities in Mali. International Crops Research Institute for the Semi-Arid Tropics. Bamako, Mali.

Biruma M, Martin T, Fridborg I, Okori P, Dixelius C (2012) Two loci in sorghum with NB-LRR encoding genes confer resistance to Colletotrichum sublineolum. Theor Appl Genet. 124:1005-1015

Boora KS, Frederiksen R, Magil C (1998) DVA-based markers for a recessive gene conferring anthracnose resistance in sorghum. Crop Sci. 38:1708-1709.

Borrel AK, Mullet JE, George-Jaeggli B, Van Oosterom EJ, Hammer GL, Klein PE, Jordan DR (2014) Drought adaptation of stay-green sorghum is associated with canopy development, leaf anatomy, root growth, and water uptake. J Exp Bot. doi:10.1093/jxb/eru232

Burrell AM, Sharma A, Patil NY, Collins SD, Anderson WF,Rooney WL, Klein PE (2015) Sequencing of an anthracnose-resistant sorghum genotype and mapping of a major QTL reveal strong candidate genes for anthracnose resistance. Crop Sci. 55: 790-799

Callaway MB, Smith ME, Coffman WR (1990) Diallel analysis of resistance to anthracnose stalk rot in maize inbreds. Crop Sci. 30:335-337.

Callaway MB, Smith ME, Coffman WR (1992) Effect of anthracnose stalk rot on grain yield and related traits of maize adapted to the north eastern United States. Canadian J. Plant Sci. 72:1031-1036.

Cardwell KF, Collins SD, Frederiksen RA (1988) Dilatory resistance character of sorghum hybrids as measured by area under disease progress curve. Biol Cultur Test. 3:36.

Cardwell KF, Hepperly PR, Frederiksen RA (1989) Pathotypes of Colletotrichum graminicola and seed transmission of sorghum anthracnose. Plant Dis. 73:255257. 1989.

Casela CR, Ferreira AS, Frederiksen RA (1993) Evidence for dilatory resistance to anthracnose in sorghum. Plant Dis. 77:908-911.

Casela CR, Ferreira AS (1995) Virulence associations in the sorghum anthracnose fungus Collectotrichum graminicola. Fitopatol Brasil. 20:33-38.

Casela CR, Frederiksen RA (1993) Survival of Collectotrichum graminicola sclerotia in sorghum stalk residue. Plant Dis. 77:825-827.

Casela CR, Pinto NFJA, Oliveria E, Ferreira AS (1997) Sorgo (Sorghum bicolor (L.) Moench): controle de doencas. In: Vale FXR, Zambolim L (ed) Control de doencas de plantas. Vicosa, M.G., Brazil: Departmento de Fitopatologia. 1025-10265

Casela CR, Ferreira AS, Santos FG (1998) Associação de virulência de Colletotrichum graminicola à resistência genética em sorgo. Fitopatol Bras. 23:143-146.

Casela CR, Santos FG, Ferreira AS (2001a) Reaction of sorghum genotypes to the anthracnose fungus Colletotrichum sublineolum. Fitopatil Bras. 26:197-200.

Casela CR, Ferreira AS, Santos FG (2001b) Differences in competitive ability among races of Colletotrichum graminicola. Fitopatol Bras. 26:217-219.

Chala A, Tronsmo AM, Brurberg MB (2011) Genetic differentiation and gene flow in Collectotrichum sublineolum in Ethiopia, the centre of origin and diversity of sorghum, as revealed by AFLP analysis. Plant Pathol. 60:474-482.

Coleman OH, Stokes IE (1954) The inheritance of resistance to stalk red rot in sorghum. Agron J. 46:61-63.

Costa RV, Casela CR, Zambolim L, Santos FG, Vale FXR (2005). Evaluation of genetic mixtures of sorghum lines for anthracnose resistance management. Fitopatol Bras. 30:525-526.

Costa RV, Zambolim L, Cota LV, da Silva DD, Rodrigues JAS, Tardin FD, Casela CR (2011) Genetic control of sorghum resistance to leaf anthracnose. Plant Pathol. 60:1162-1168.

Cuevas HE, Prom LK, Erpelding JE (2014) Inheritance and molecular mapping of anthracnose resistance genes present in sorghum line SC112-14. Mol Breed. 34:1943-1953.

Dogget HD (1988) Sorghum. 2nd ed. Longman Group UK, Green and Co. Ltd, London, Harlow, England.

Esele JP (1995) Foliar and head diseases of sorghum. Afr Crop Sci J. 3(2):185-189, 
Ezzat EM, Ali MA, Mahmoud AM (2010) Agronomic Performance, Genotype X Environment interactions and stability analysis of grain sorghum (Sorghum bicolor L. Moench). J Crop Sci. 2(4):250-260.

FAO (2011). FAOSTAT. http:/faostat.fao.org.

Felderhoff JT, McIntyre ML, Saballos A, Vermerris W (2016) Using genotyping by sequencing to map two novel anthracnose resistance loci in Sorghum bicolor. G3 Bethesda 6(7):1935-1946.

Ferreira AS, Casela CR (1986) Races patogenices de Colletotrichum graminicola, agent causal de anthracnose em sorgo [Sorghum bicolor (L.) Moench]. Fitopatol Brasil. 11:833-887.

Figueiredo JEF, Depaoli HC, da Silva Coelho VT, Casela CR, da Silva Ferreira A, Guimaraes CT, Gomes EA, Bressan W (2006) Genetic diversity among Collectotrichum sublineolum pathotypes isolated from sorghum (Sorghum bicolor). Rev Bras Milho Sorgo. 5:304318.

Griffing B (1956) Concept of general and specific combining ability in relation to diallel crossing systems. Aust J Biol Sci. 9:463-493.

Guimarães FB, Casela CR, Santos FG, Ferreira AS (1998) Controle da antracnose do sorgo através da utilização de mistura de cultivares. Summa Phytopathol. 24:131-135.

Guthrie PAI, Magill CW, Frederiksen RA, Odvody G (1992) Random amplified polymorphic DNA markers: A system for identifying and differentiating isolates of Collectotrichum graminicola. Phytopathol. 82:832-835.

Haris HB, Johnson BJ (1967) Sorghum anthracnose symptoms, importance and resistance. Proc. Biennial Grain Sorg. Res. And Util Conf. 5:48-52.

Heath M (1981) A generalized concept of host-parasite specificity. Phytopathol. 71:1121-1123.

Hovny MRA, Mahmoud KM, Ali MA, Ali HI (2005) The effect of environment on performance, heterosis and combining ability in grain sorghum (Sorghum bicolor (L.) Moench). Proceedings of the 11th Conference of Agronomy. Agronomy Department, Faculty Agriculture, Assiut University, 689-699. 15-16 November1978

ICRISAT (2009) Sorghum. ICRISAT, Andhra Pradesh, India.

Katile SO (2007) Expression of defense genes in sorghum grain mold and tagging and mapping a sorghum anthracnose resistance gene. PhD Dissertation. University of Texas A \&M. USA.

Klein RR, Rodriguez-Herrera R, Schlueter JA, Klein PE, Yu ZH, Rooney WL (2001) Identification of genomic regions that affect grain-mould incidence and other traits of agronomic importance in sorghum. Theor Appl Genet. 102:307-319.

LeBaeau FJ, Coleman OH (1950) The inheritance of resistance in sorghum to leaf anthracnose. Agron J. 42:3334

Marley PS, Thankur RP, Ajayi O (2001) Variation among foliar isolates of Collectotrichum sublineolum of sorghum in Nigeria. Field Crops Res. 69:133-142.

Marley PS, Diourte M, Neya A., Rattunde FRW (2004) Sorghum anthracnose and sustainable management in West and Central Africa. J. Sustain Agric. 25:43-56.

Marley PS, Diourte M, Neya A., Rattunde FW (2005) Sorghum anthracnose and sustainable management strategies in West and Central Africa. J Sustain Agric. 25:43-56

Mathur K, Thakur RP, Neya A, Marley PS, Casela CR (2002) Sorghum anthracnose-problem and management strategy.
In: Leslie, J.F. (ed.) Sorghum and millets diseases. Iowa State Press. Ames, Iowa, USA. 211-220

Mehta PJ, Wiltse CC, Rooney WL, Collins SD, Frederiksen RA, Hess DE, Chisi M, TeBeest DO (2005) Classification and inheritance of genetic resistance to anthracnose in sorghum. Field Crop Res. 93:1-9.

Michereff SJ, Silveira NSS, Mariano RL (1994) Antagomism of bacteria to Collectotrichum graminicola and potential for biocontrol of sorghum anthracnose. Fitapatol Brasil. 19:541-545.

Moore JW, Ditmore M, TeBeest, DO (2008) Pathotypes of Colletotrichum sublineolum in Arkansas. Plant Dis. 92:1415-1420.

Murali Mohan S, Madhusudhana R, Mathur K, Chakravarthi DVN, Rathore S, Nagaraja Reddy R, Satish S, Srinivas G, Sarada Mani N, Seetharama N (2010) Identification of quantitative trait loci associated with resistance to foliar diseases in sorghum [Sorghum bicolor (L.) Moench] Euphytica 176:199-211

Murty DS, Thomas MD (1989) Preliminary studies on the inheritance of resistance to leaf anthracnose and gray leaf spot disease of sorghum (Sorghum bicolor (L.) Moench). Sorghum Newsletter 31:83.

Neya A, Normand LE (1998) Response of sorghum genotypes to leaf anthracnose (Collectotrichum graminicola) under field conditions in Burkina Faso. Crop Prot. 17:47-53.

Ngugi HK, Julian AM, King SB, Peacocke BJ (2000) Epidemiology of sorghum anthracnose (Colletotrichum sublineolum) and leaf blight (Exserohilum turcicum) in Kenya. Plant Pathol. 49:129-140.

Ozula KOO, Tyagi PD, Emechebe AA (1986) Pathogenic variation in Collectotrichum graminicola, the causal agent of anthracnose of sorghum in Nigeria. Nigerian J Plant Prot. 10:37-44

Panday S, Sindhu A, Boora KS (2002) RAPD based DNA markers linked to anthracnose disease resistance in Sorghum bicolor (L.) Moench. Indian J. Exp Biol. 40:20 211

Park SD, Park KS, Kim KJ, Kim JC, Yoon JT, Khan Z (2005) Effect of sowing time on development of safflower anthracnose disease and degree of resistance in various cultivars. J Phytopathol. 153:48-51.

Parlevliet JE (1979) Components of resistance that reduce the rateof epidemic development. Ann Rev Phytopathol. 17:203-222.

Perumal RMA, Menz PJ Mehta, Katile S, Giutierrez-Rojas LA, Klein RR, Klein PE, Prom LK, Schlueter JA, Rooney WL, Magill CW (2009) Molecular mapping of $C g 1$, a gene for resistance to anthracnose (Colletotrichum syublineolum) in sorghum. Euphytica. 165:597-606.

Plank JVD (1963) Plant diseases: epidemics and control. Pp.223. In: Plant diseases: epidemics and control. Academic Pres, New York.

Qwary DM, Asala SW (2006a) Progress of sorghum leaf anthracnose. Int J Agric Biol. 8:309-312.

Qwary DM, Asala SW (2006b) Cost-benefit of fungicidal control of anthracnose on sorghum in northern Nigeria. Int J Agric Biol. 8:306-308.

Rooney WL, Collins SD, Klein RR, Mehta PJ, Frederiksen RA, Rodriquez-Herrera R (2002) Breeding sorghum for resistance to anthracnose, grain mold, downy mildew and head smut. In: Leslie JF (ed) Sorghum and millets diseases. Iowa State Press. Ames, Iowa, USA. 273-279

Rooney WL, Odvody GN, Schaefer K, Collins SD (2011) Registration of Tx2929 through Tx2934 sorghum germplasm. J Plant Reg. 5(1):123-127. 
Rosewich UL, Pettway RE, McDonald BA, Duncan RR, Frederiksen RA (1998) Genetic structure and temporal dynamics of a Collectotrichum graminicola population in a sorghum disease nursery. Phytopathol. 88:1087-1093.

Saeed M, Francis CA (1983) Yield stability in relation to maturity in grain sorghum. Crop Sci. 23(4):683-687.

Silva DD, Casela CR, Castro HA, Santos FG, Ferreira AS (2008) Diversidade populational de Colletotrichum sublineolum, em seis localidades no Brasil. Summa Phytopathol. 34:149-155.

Singh M, Shukla P, Sharma SK (1989) Chemical control of anthracnose disease of jowar (Sorghum vulgare Pers.) Farm Sci J. 4:121-123.

Singh MK, Chaudhary HR, Singal CW, Magill W, Boora KS (2006) Identification and characterisation of RAPD and SCAR markers linked to anthracnose resistance gene in sorghum [Sorghum bicolor (L.) Moench]. Euphytica 149:149-187.

Singh M. Boora KS (2008) Molecular characterisation of anthracnose resistance gene in sorghum. In: Rao, G.P., R.K. Singh, and M.L. Sharma (ed.), Plant Genomics and Bioinformatics, Stadium Press LLC, Houston, Texas, USA. 373-388

Somda I, Leth V, Sarama P (2007) Evaluation of Lemongrass, Eucalyptus and Neem aqueous extracts for controlling seed-borne fungi of sorghum grown in Burkina Faso. World J Agric Sci. 3:218-223.

Tenkouano A (1993a) Genetic and ontogenic analysis of anthracnose resistance in Sorghum bicolor (L.) Moench. $\mathrm{PhD}$ thesis. College Station, Texas A\&M University, TX, USA.

Tenkuano A, Miller FR, Hart GE, Frederiksen RA, Nicholaon RL (1993b) Phytoalexin assay in juvenile sorghum: An aid to breeding for anthracnose resistance. Crop Sci. 33:243-248.

Tenkouano A, Miller FR (1993) A single locus with multiple alleles as the genetic basis of anthracnose resistance in sorghum. Sorghum Newsletter 34:45.

Tesso T, Perumal R., Little CR, Adeyanju A, Radwan GL, Prom LK, Magill CW (2012). Sorghum pathology and biotechnology - a fungal disease perspective: Part II. Anthracnose, stalk rot and downy mildew. Eur J Plant Sci Biotechnol. 6:31-44.

Thakur RP, Mathur K (2000) Anthracnose. In: Frederiksen RA, Odvody GN, (ed). Compendium of sorghum diseases. The American Phytopathological Society, St. Paul, MN, USA. 10-12

Thakur RP, Reddy BVS, Mathur K (2007) Screening techniques for sorghum diseases. Information Bulletin No. 76. Patencheru 502 324, Andhara Pradesh, India: International Crops Research Institute for the Semi-Arid Tropics. 96.
Thomas MD (1995) Sorghum anthracnose research in West Africa: A look at the present and the future. Leslie JF, Frederiksen R.A. (ed) Disease analysis through genetics and biotechnology, interdisciplinary bridges to improve sorghum and millet crops. Iowa University Press. Ames, Iowa, USA. 127-136

Thomas MD, Frederiksen RA (1995) Fertility tests on sorghum isolates of Colletotrichum graminicola from West Africa. Int Sorghum Millets Newslett. 36:79.

Thomas, MD, Rosewich UL, Frederiksen RA (1995) Preliminary studies of total DNA restriction fragment length polymorphism (RFLP) on West African isolates of Collectotrichum graminicola from sorghum. Int Sorghum Millet Newslett. 36:90-93.

Upadhyaya HD, Wang YH, Sharma R, Sharma S (2013) Identification of genetic markers linked to anthracnose resistance in sorghum using association analysis. Theor Appl Genet. 126:1649-1657.

Valerio H, Resende M., Weikert-Oliveira R, Casela C (2005) Virulence and molecular diversity in Colletotrichum graminicola from Brazil. Mycopathol. 159:449-459.

Van den Berg J, Drinkwater TW (1997) Field guide to identification of sorghum pests in Southern Africa. Agricultural Research Council-Grain Crops Institute, Potchefstroom, South Africa.

Vijayakumar M, Jayanthi C, Kalpana R, Ravisankar D (2014) Integrated weed management in sorghum [Sorghum bicolor (L.) Moench] - a review. Agric Rev. 35 (2):79-91.

Vuylsteke, M, Eeuwijk F (2008) The use of general and specific combining abilities in a context of gene expression relevant to plant breeding. Euphytica. 161:115-122.

Wang ML, Dean R, Erpelding J, Pederson G (2006) Molecular genetic evaluation of sorghum germplasm differing in response to fungal diseases: Rust (Puccinia purpurea) and anthracnose (Collectotrichum graminicola). Euphytica. 148:319-330.

Warren HL (1986) Leaf anthracnose. Pp. 10-11. In: Frederiksen R.A. (Ed.), Compendium of sorghum diseases. American Phytopathology Society, USA.

White DG, Yanney J, Natti TA (1979) Anthracnose stalk rot. Proc. Ann. Corn and Sorghum Res. Conf. 34:1.15.

Zidenga T (2004) DNA-based methods in sorghum diversity studies and improvement. ISB News Report. Plant Biotechnology Centre, Ohio State University. 